\title{
FGFR2 Positive
}

National Cancer Institute

\section{Source}

National Cancer Institute. FGFR2 Positive. NCI Thesaurus. Code C134497.

An indication that FGFR2 expression has been detected in a sample. 